\title{
Heavy metal bioaccumulation in two passerines with differing migration strategies
}

\author{
Zoë Cooper ${ }^{\mathrm{a}, \mathrm{b},{ }^{*}}$, Robert Bringolf ${ }^{\mathrm{a}}$, Robert Cooper ${ }^{\mathrm{a}}$, Kathy Loftis ${ }^{\mathrm{c}}$, Albert L. Bryan ${ }^{\mathrm{b}}$, James A. \\ $\operatorname{Martin}^{\mathrm{a}, \mathrm{b}}$
}

\footnotetext{
${ }^{a}$ University of Georgia, Warnell School of Forestry and Natural Resources, 180 E. Green St. Athens, GA 30602, USA

${ }^{\mathrm{b}}$ University of Georgia, Savannah River Ecology Laboratory, P.O. Drawer E, Aiken, SC 29803, USA

${ }^{\mathrm{c}}$ University of Georgia, Center for Applied Isotope Studies, 120 Riverbend Rd. Athens, GA 30602, USA
}

* Corresponding author at: University of Georgia, Warnell School of Forestry and Natural Resources, 180 E. Green St. Athens, GA 30602, USA

Email addresses: zoe.cooper@uga.edu (Z.Cooper), bringo@uga.edu (R. Bringolf), rcooper@warnell.uga.edu (R. Cooper), kloftis@uga.edu (K. Loftis), lbryan@ srel.uga.edu (A.L. Bryan), martinj@warnell.uga.edu (J.A. Martin) 


\subsection{Introduction}

Since the environmental revolution of the 1970s, cleanup efforts from anthropogenic environmental pollutants have been conducted nationwide, yet decades later residual repercussions to wildlife are still widespread. Heavy metal contamination results from improper disposal or release of specific chemical and nuclear byproducts. These metals can include essential (e.g., Se, Zn, and $\mathrm{Cu}$ ) and non-essential elements (e.g., $\mathrm{Hg}, \mathrm{Pb}, \mathrm{Cd}, \mathrm{Cr}$, As, and $\mathrm{Ni}$ ) with some exhibiting high toxicity at low concentrations. Biomonitoring of organisms inhabiting potentially polluted areas yields an assessment of overall ecosystem health (Burger and Gochfeld, 1996). Many of the current biomonitoring efforts rely on samples taken from aquatic organisms related to possible human consumption risks. However, many terrestrial organisms also consume resources from contaminated aquatic ecosystems exposing them to such pollutants.

Higher trophic level organisms, such as piscivorous birds and raptors, have been extensively studied and monitored for heavy metals (Battaglia et al., 2005; Lodenius and Solonen, 2013; Movalli, 2000; Solonen and Lodenius, 1990); however, heavy metal contamination from an aquatic source can bioaccumulate to levels sufficient to negatively affect organisms at a lower trophic level (Edwards et al., 2014). Jackson et al. (2011) indicated terrestrial songbird reproductive success was reduced in the terrestrial environment surrounding rivers contaminated by heavy metals. Chronic exposure to certain heavy metals can cause physiological abnormalities (Scheuhammer, 1987), reducing reproductive success (Jackson et al., 2011) which could lead to local population level changes. Songbirds are low- to mid- trophic level organisms and have the ability to accumulate heavy metals through air, food, or water resources but most often through dietary intake (Burger and Gochfeld, 2002). Assessing their exposure to environmental pollution can be indicative of overall ecosystem health from a ecotoxicological 
standpoint (Abbasi et al., 2015; Brait and Antoniosi- Filho, 2011; Burger and Gochfeld, 2000; Scheifler et al., 2006) and provide information of heavy metals in the environment of which they reside in (Dauwe et al., 2002; Eens et al., 1999; Furness and Greenwood, 1993; Goede and de Bruin, 1984; Lodenius and Solonen, 2013).

Once inside the body, metals accumulate in internal tissues, are excreted in feces, or are deposited in feathers (Burger, 1993). Metal concentrations in feathers can provide information on body burdens at time of molt and feather growth (Dauwe et al., 2000), especially for mercury (Bearhop et al., 2000), but relationships between feather concentrations and body burdens vary greatly among metals (Beyer and Meador, 2011). Metal levels in blood provide an indication of recent short-term dietary exposure (Furness and Greenwood, 1993) before being excreted or accumulated into internal tissues. Both blood and feather concentrations supply dietary information on site-specific uptake of metals such as methylmercury (Evers et al., 2005). Mercury concentrations in blood and feather tissues are generally strongly correlated (Ackerman et al., 2011). Although it has been suggested that all other metal concentrations in feathers are related to external (atmospheric deposition) contamination (Dauwe et al., 2003), this suggestion has been questioned (Beyer and Meador, 2011; Burger, 1993).

Feathers obtained from migratory species indicate exposure to contaminants throughout the year as these birds molt and regrow feathers between breeding and wintering grounds (Braune et al., 2002). Concentrations in resident birds are likely sourced locally and can be used to identify contaminated areas (Burger, 1993). With very large home ranges, migrants are better adapted to handling toxic compounds (Rainio et al., 2012). Migratory birds have a higher basal metabolic rate (BMR) than non-migratory birds (Jetz et al., 2008) which would suggest that heavy metals 
are absorbed more rapidly into the body in migrants resulting in lower blood concentrations (Cai and Calisi, 2016) although this hypothesis has not been explored thoroughly.

Biomonitoring studies on songbirds rarely report the sex of individuals sampled though sexspecific differences in physiology and behavior could affect heavy metal concentrations (Deng et al., 2007; Robinson et al., 2012). For example, foraging behavior of passerines often differs among sexes during the breeding season based on their space use (Holmes, 1986) which, generally speaking, means that males forage at higher heights near song perches while females forage lower at nest heights. This contrast between sexes can explain the relationship of differing feeding habitats and bioaccumulation/detoxification rates (Fossi et al., 1995). Also, females have been shown to deposit trace elements into eggs and eggshells providing an alternative pathway of excretion compared to males during the breeding season (Burger, 2007) leading to decreased body burden. However, female to egg metal deposition rates are not consistent among species (Robinson et al., 2012).

The objectives of this study were to 1) determine the geographic extent of heavy metal contamination in songbirds in association with potentially bioavailable contaminated (PBC) sites on the U.S. Department of Energy's Savannah River Site (SRS), 2) evaluate the congruence of two non-lethal sampling techniques, 3) compare location-specific metal concentrations between a migratory songbird, Great Crested Flycatcher (Myiarchus crinitus) and a resident songbird, Northern Cardinal (Cardinalis cardinalis), and 4) assess the differences in metal concentrations between sexes. We hypothesize that feather concentrations from Great Crested Flycatchers will be similar across sites as these feathers were grown prior to reaching the SRS while Northern Cardinals will have higher levels in their feathers at PBC locations because they reside there year round (hereafter, migratory exposure hypothesis). We also hypothesize that both species with 
individuals breeding in close proximity to $\mathrm{PBC}$ areas will have higher concentration levels in their blood (and feathers for Northern Cardinals) compared to birds breeding in reference locations (hereafter, close proximity hypothesis).

\subsection{Methods}

\subsubsection{Study Species}

Northern Cardinals (hereafter, cardinals) are an example of a year-round omnivorous resident species in eastern North America that generally spends its entire adult life within $2.3 \mathrm{~km}$ of its breeding territory (Halkin and Linville, 1999) which makes them an ideal species for biomonitoring of metals in a specific geographic location over a greater period of time compared to a migratory species. Great Crested Flycatchers (hereafter, flycatchers) migrate to our study area to breed from April to August and maintain a higher trophic level than cardinals as the majority (93\%) of their diet consists of invertebrates (Miller and Lanyon, 2014). Cardinals complete a full molt from October - November while flycatchers body molt is poorly understood but likely takes place on or near wintering grounds in Central America from March-May (Dickey and van Rossem, 1938; Miller and Lanyon, 2014).

\subsubsection{Study Area}

The study was conducted on the U.S. Department of Energy's Savannah River Site (SRS) south of Aiken, South Carolina and the Silver Bluff Audubon Center property west of Jackson, South Carolina. The SRS is approximately $800 \mathrm{~km}^{2}$ in size and was originally constructed in the 1950s to aid in the production of materials used for nuclear weapons. This region is characterized by a humid subtropical climate with an average annual precipitation of 1,225 $\mathrm{mm}$ and rarely sees ice or snowfall (Kilgo and Blake, 2005). Currently, more than 50\% of the area is longleaf (Pinus 
palustris) or loblolly pine (Pinus taeda) forest and about $20 \%$ hardwoods with a variety of other habitat-types occupying the remaining land (Kilgo and Blake, 2005). Large sections along the Savannah River are seasonally flooded wetlands and flood plains with several oak species (Quercus spp.), sweetgum (Liquidambar styraciflua), and hickories (Carya spp.) dominating the canopy and swamp palmetto (Sabal minor), winged elm (Ulmus alata), and hawthorns (Crataegus spp.) dominating the understory. Riparian areas along small stream bottoms contain a mix of tulip poplar (Liriodendron tulipifera), sweetgum (Liquidambar styraciflua), water oak (Quercus nigra), and American holly (Ilex opaca) as canopy species and switch cane (Arundinaria tecta), blueberries (Vaccinium spp.), red bay (Persea borbonia), dog hobble (Leucothoe axillaris) and blackhaw (Viburnum prunifolium) in the understory.

\subsubsection{Study design}

We sampled in four randomly selected locations in bottomland hardwood/floodplain along streams or the Savannah River in Aiken or Barnwell County. Each location was 11-28 km apart. Two locations were deemed reference locations (Silver Bluff and Upper Three Runs) due to their distance $(>10 \mathrm{~km})$ upstream from known or possibly contaminated areas and two locations were designated potentially bioavailable contaminated locations (PBCs: D-Area and Pen Branch) as they were in close proximity (approximately $2-4 \mathrm{~km}$ ) to historically contaminated areas (Figure 1). Surface and well water along with sediment samples are collected on the SRS annually at minimum and are analyzed for many contaminants including metals (http://www.srs.gov/general/pubs/ERsum/index.html). This information has yielded some areas of higher than normal concentrations of metals. D-Area contains coal fly ash basins and drainage swamps that, in other studies, have shown heavy metal uptake by many wildlife species (Hernández et al., 2016; Hopkins et al., 1998; Rowe et al., 1996) including aquatic invertebrates 
(Fletcher et al., 2014). One study at D-Area found maternal transfer of trace elements from common grackles to their young living along the basin (Bryan et al., 2003). Pen Branch, while less studied, has a history of heavy metal contamination in aquatic vertebrates and invertebrates (Bryan, 2011; Loehle and Paller, 1990) indicating potential for trophic transfer from the environment.

We opened mist nets 50-200m apart at each location approximately 15-30 minutes before sunrise and closed the nets by $1100 \mathrm{hrs}$ or earlier if temperatures exceeded acceptable limits (i.e., $\sim 29^{\circ} \mathrm{C}$ ). Edges between hardwoods and other habitat types were frequently used as areas to set up mist nets. We targeted flycatchers and cardinals either passively or by playback of conspecific calls and songs from April -June 2016. Once caught, each bird was sexed and given an aluminum USGS band (USGS BBL Permit Number 22002). We collected 8-12 breast feathers per individual and stored them in a marked and sealed plastic bag until analysis (Institutional Animal Care and Use Committee Permit Number A2016 02-022-Y1-A0). Blood samples ( 0.10$0.30 \mathrm{ml}$ ) were collected from the jugular vein of each individual, placed in lithium heparin tubes, and stored on ice until analysis. We released individuals immediately upon sample collection completion.

\subsubsection{Sample treatment and analysis}

\section{Feather treatment and analysis}

Feathers were pre-treated to remove external contamination. Before analysis, feathers were sonicated for 15 minutes in $18 \mathrm{M} \Omega$ water, followed by a rinse with $18 \mathrm{M} \Omega$ water. The feathers were then dried at $60^{\circ} \mathrm{C}$ to a constant weight before determining dry weight. Whole feathers were digested in PFA vials with trace-metal grade $\mathrm{HNO}_{3}$ at $70^{\circ} \mathrm{C}$ for 24 hours following a method modified by Bond and Lavers (2011). Trace-metal grade $\mathrm{H}_{2} \mathrm{O}_{2}$ was added and the 
samples were heated at $70^{\circ} \mathrm{C}$ for an additional $3 \mathrm{~h}$. After digestion, the samples were diluted with $18 \mathrm{M} \Omega$ water. Procedural blanks were prepared in the same manner alongside samples to monitor for potential contamination.

\section{Blood treatment and analysis}

Blood samples were pre-digested for $24 \mathrm{~h}$ in trace-metal grade $\mathrm{HNO}_{3}$. Samples were then heated at $90^{\circ} \mathrm{C}$ for 3 hours. Trace-metal grade $\mathrm{H}_{2} \mathrm{O}_{2}$ was added and samples were heated for an additional hour at $90^{\circ} \mathrm{C}$. Samples were diluted with $18 \mathrm{M} \Omega$ water. Procedure blanks were prepared in the same manner alongside samples to monitor for potential contamination.

\section{Metal Analysis}

Samples were analyzed at the Center for Applied Isotope Studies, University of Georgia for eight trace metals (As, $\mathrm{Cd}, \mathrm{Cr}, \mathrm{Cu}, \mathrm{Ni}, \mathrm{Pb}, \mathrm{Se}$, and $\mathrm{Zn}$ ) by ICP-MS (VG Elemental PQ3) in solution mode. Detection limits were as follows: As $0.042 \mu \mathrm{g} / \mathrm{mg}, \mathrm{Cd} 0.006 \mu \mathrm{g} / \mathrm{mg}, \mathrm{Cr} 0.027$ $\mu \mathrm{g} / \mathrm{mg}, \mathrm{Cu} 0.102 \mu \mathrm{g} / \mathrm{mg}$, Ni $0.159 \mu \mathrm{g} / \mathrm{mg}, \mathrm{Pb} 0.012 \mu \mathrm{g} / \mathrm{mg}$, Se $0.228 \mu \mathrm{g} / \mathrm{mg}$, and Zn 0.213 $\mu \mathrm{g} / \mathrm{mg}$. Indium was used as an internal standard. All samples were analyzed with certified QC standards and blanks. Elemental analysis was performed using the quantitative analysis method. Samples that were below detection limit were given a value of one-half the detection limit for each metal prior to statistical analysis.

\subsubsection{Mercury analysis}

Feather and blood samples were analyzed for total mercury (Hg) according to US EPA method 7473 using a Milestone DMA-80 (Savannah River Ecology Laboratory, Aiken, SC). Feather samples consisted of 2-3 whole breast feathers that had been washed and dried using the same method previously described. Quality assurance samples were run every 10-20 samples which included blanks and certified reference materials (PACS-2 and TORT-3; National 
Research Council Canada). Duplicate feather samples $(n=18)$ were run after approximately every 10 feather samples and sample averages were taken for statistical analysis. Analytes were reported in parts per million on a dry weight ( $\mathrm{dw}$ ) basis with an average detection limit of 0.123 $\mu \mathrm{g} / \mathrm{mg}$ (ppb). Recovery of standard reference materials was 100.6\% (range $=96.6-104.3 \%$ ) for TORT-3 and 96.6\% (range $=88.2-116.6 \%$ ) for PACS-2. Blood samples were freeze-dried prior to analysis due to clotting issues to ensure the entire sample was homogenous and could be extracted. Using a wet weight (ww)/dw ratio from Newman et al. (2011), we converted the dw concentration of the blood samples to ww concentrations to facilitate comparison to other published studies.

\subsubsection{Statistical Analysis}

Linear mixed-effects models were used to analyze the data with independent variables being species, sex, and site (PBC or reference locations). A random effect of site was also included because multiple samples were taken at each site. We used the lmer function from package lme4 (Bates et al., 2015) in R (version 3.2.3, R Core Team, 2015) to fit models. Models were compared using Akaike information criteria adjusted for small sample size $\left(\mathrm{AIC}_{\mathrm{c}}\right)$ (Arnold, 2010; Burnham and Anderson, 2002). AIC $_{c}$ values were calculated using maximum likelihood and used for model comparison and to estimate model coefficients, but $r^{2}$ values were calculated using restricted maximum likelihood (Nakagawa and Schielzeth, 2013). Models were considered competing if $\Delta \mathrm{AIC}_{\mathrm{c}}<4$ and model averaging was implemented to determine full model averaged coefficients. Biological significance was determined with $85 \%$ confidence intervals that did not cross zero (Arnold, 2010). Spearman rank correlation tests were used to determine correlations between feather and blood samples among species and a few metal groups with a significance value set at $\alpha=0.05$. 


\subsection{Results}

3.1.1 Trace metals between species and location groups

Four sites were sampled across the study area (two PBC and two reference) with 70 total birds captured (37 in reference and 33 in PBC) and sampled from April-June 2016. Overall mean values in blood and feather samples for both species were relatively low for all metals analyzed (Table 1 and 2). More than $90 \%$ of the cadmium values for both tissue types were below 0.01 $\mu \mathrm{g} / \mathrm{g}$ and were excluded from further statistical analysis.

We did not find support for our close proximity hypothesis based on blood concentrations for any metal analyzed (see supplemental material for all AICc tables). We found an unpredicted pattern of a significant species and specific site group (reference/PBC) interaction with greater $\mathrm{Cu}$ concentrations for cardinal feathers in the reference sites than flycatchers in the same location $(\beta=5.226,85 \% \mathrm{CL}=0.939,9.513$; Figure 2$)$; however, birds overall in reference sites expressed decreased $\mathrm{Cu}$ concentrations $(\beta=-5.162,85 \% \mathrm{CL}=-9.089,-1.235$; Figure 2$)$ compared to PBC sites. Cardinals had less $\mathrm{Cr}$ in feathers than flycatchers overall $(\beta=-1.463$, $85 \% \mathrm{CL}=-2.436,-0.489$; Figure 3) but all birds in reference sites had lower $\mathrm{Cr}$ feather concentrations $(\beta=-1.361,85 \% \mathrm{CL}=-2.641,-0.081$; Figure 3$)$ than PBC sites. 


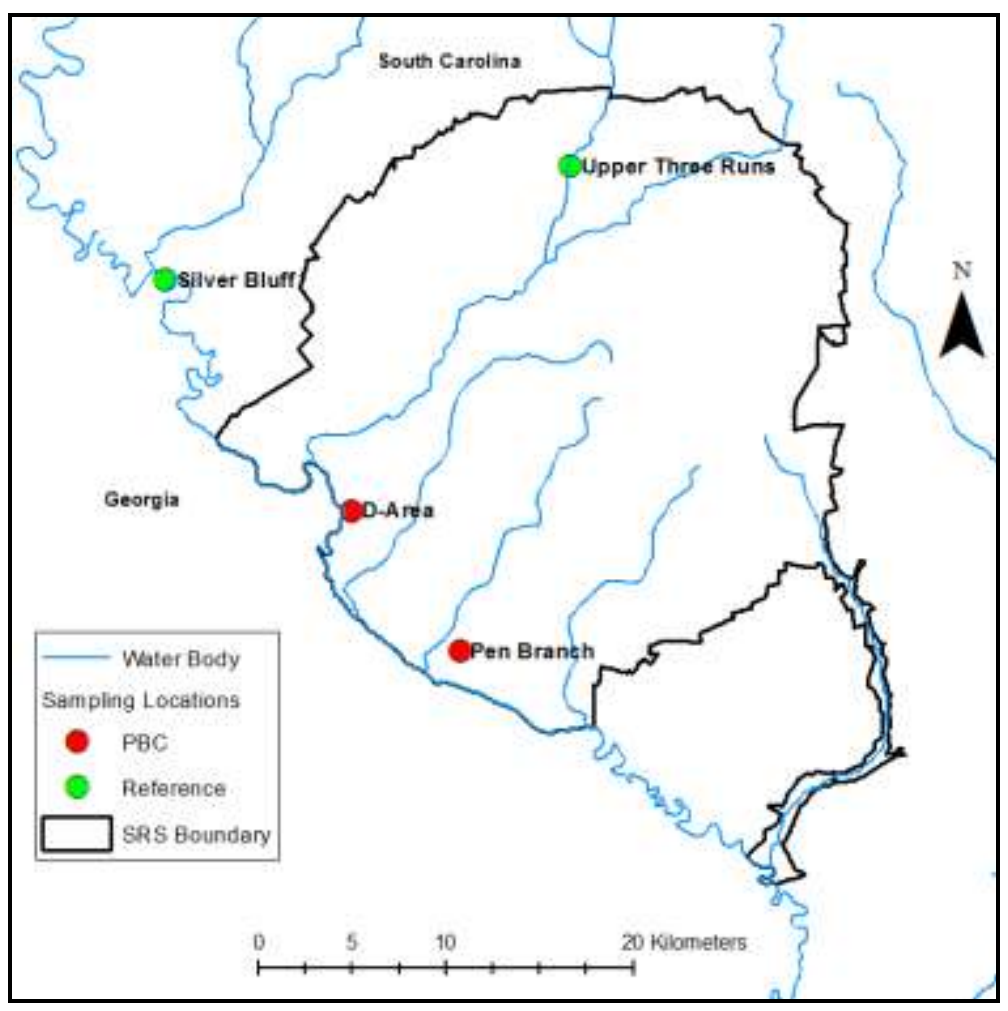

Figure 1: Map of the Savannah River Site (SRS) with major streams, branches, and tributaries with sampling locations denoted as potentially bioavailable contaminated (PBC) or reference.

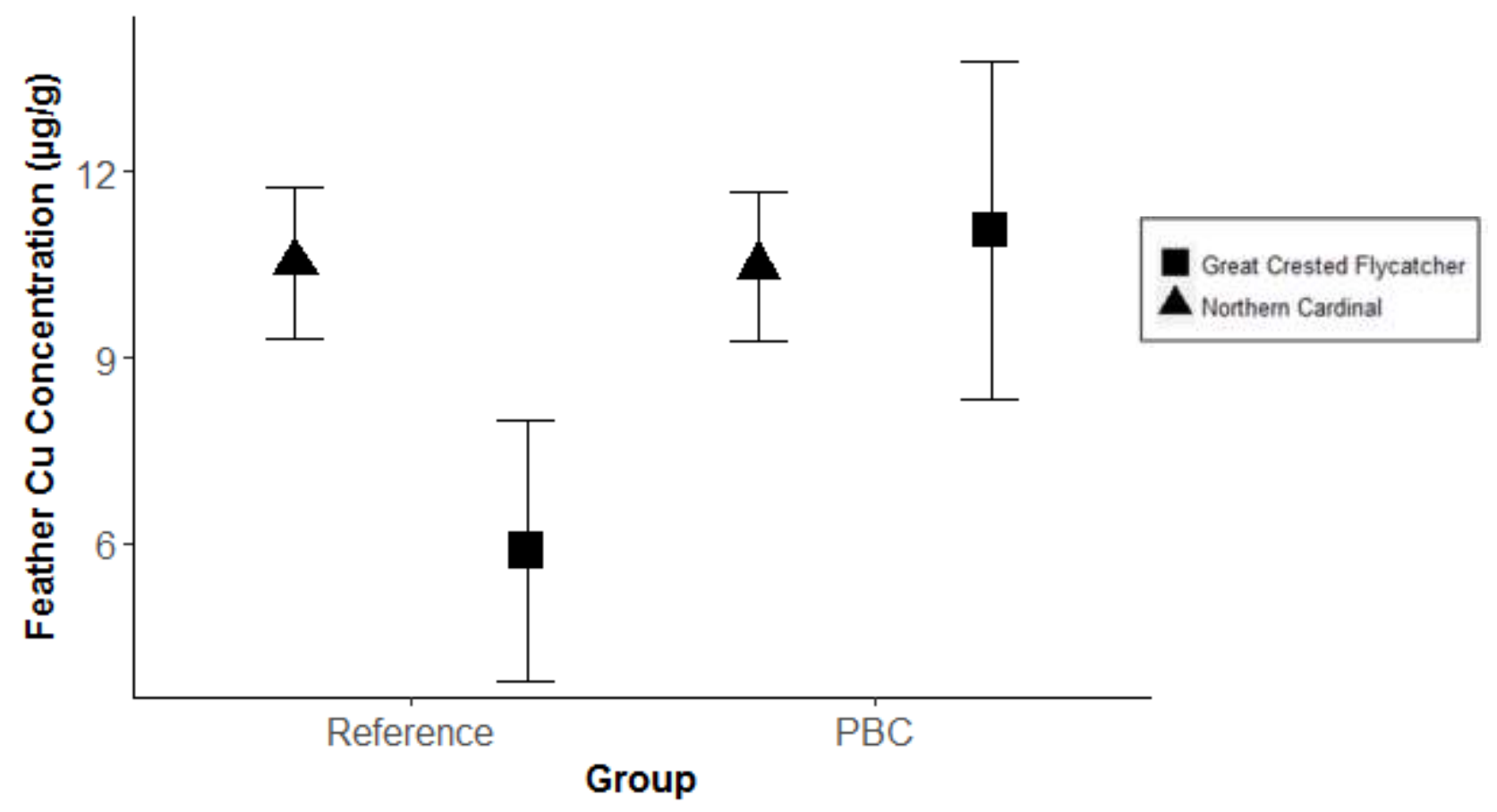

Figure 2: Predicted feather concentrations levels (dry weight) of copper $(\mathrm{Cu})$ after model averaging $(85 \%$ confidence interval) for Northern Cardinals (triangle, $n=50$ ) and Great Crested Flycatchers (square, $n=20$ ) collected at the Savannah River Site April-June 2016. 


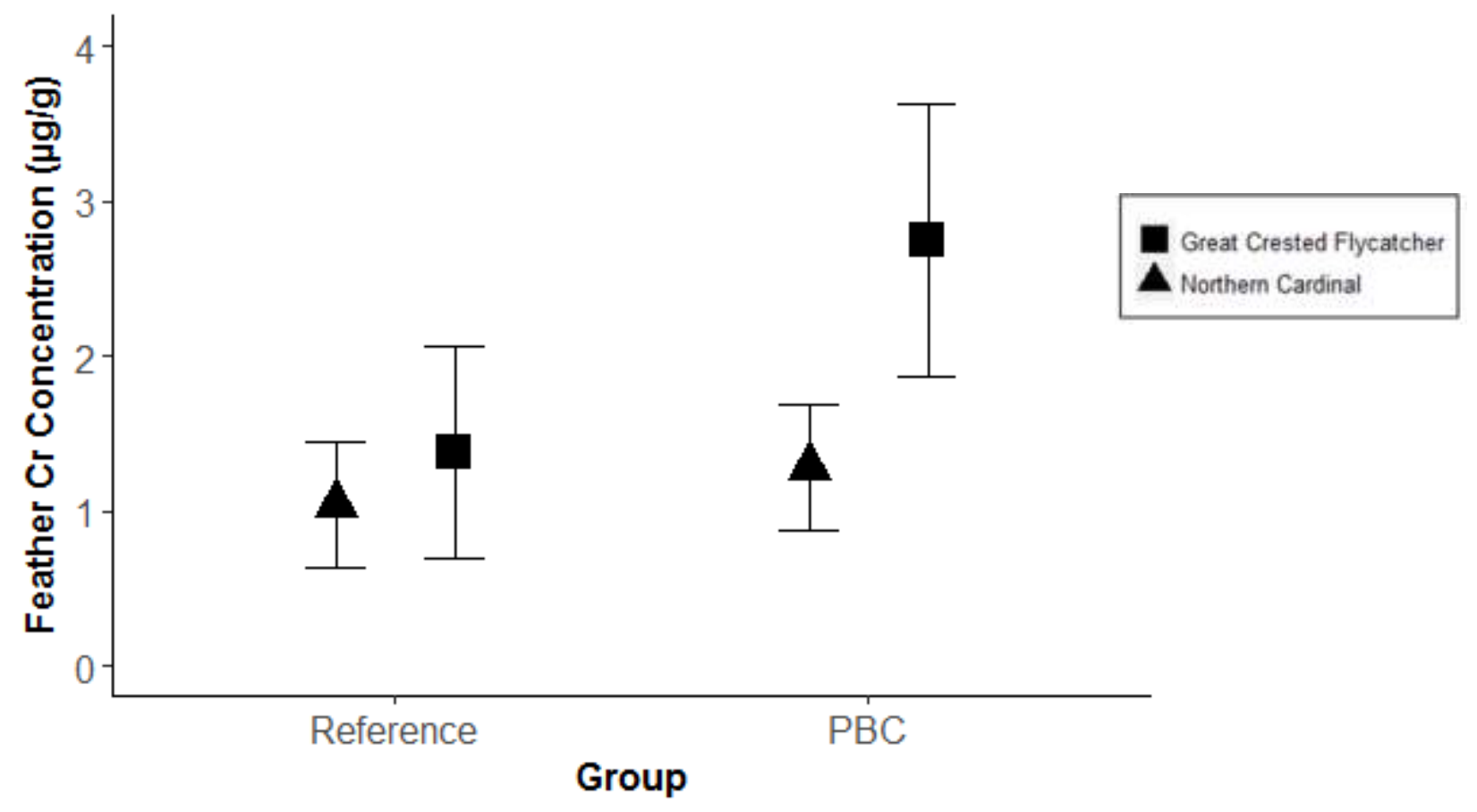

Figure 3: Predicted feather concentrations levels (dry weight) of chromium ( $\mathrm{Cr})$ after model averaging $(85 \%$ confidence interval) for Northern Cardinals (triangle, $n=50)$ and Great Crested Flycatchers $($ square, $n=20)$ collected at the Savannah River Site April-June 2016.

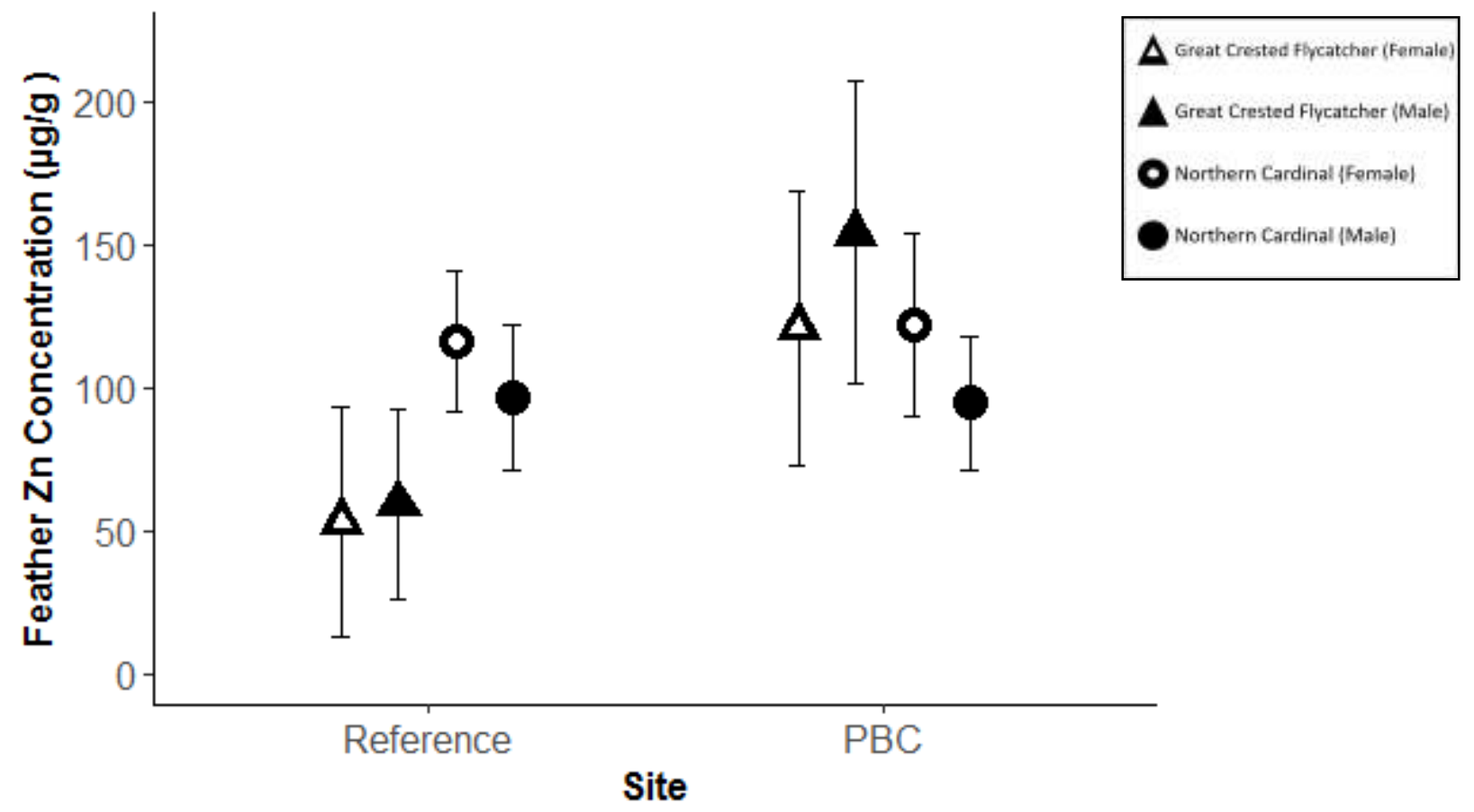

Figure 4: Predicted feather concentrations levels (dry weight) of zinc ( $\mathrm{Zn}$ ) after model averaging (85\% confidence interval) for Northern Cardinals (circle, $n=50$ ) by sex and Great Crested Flycatchers (triangle, $n=20$ ) by sex that were collected at the Savannah River Site April-June 2016. 


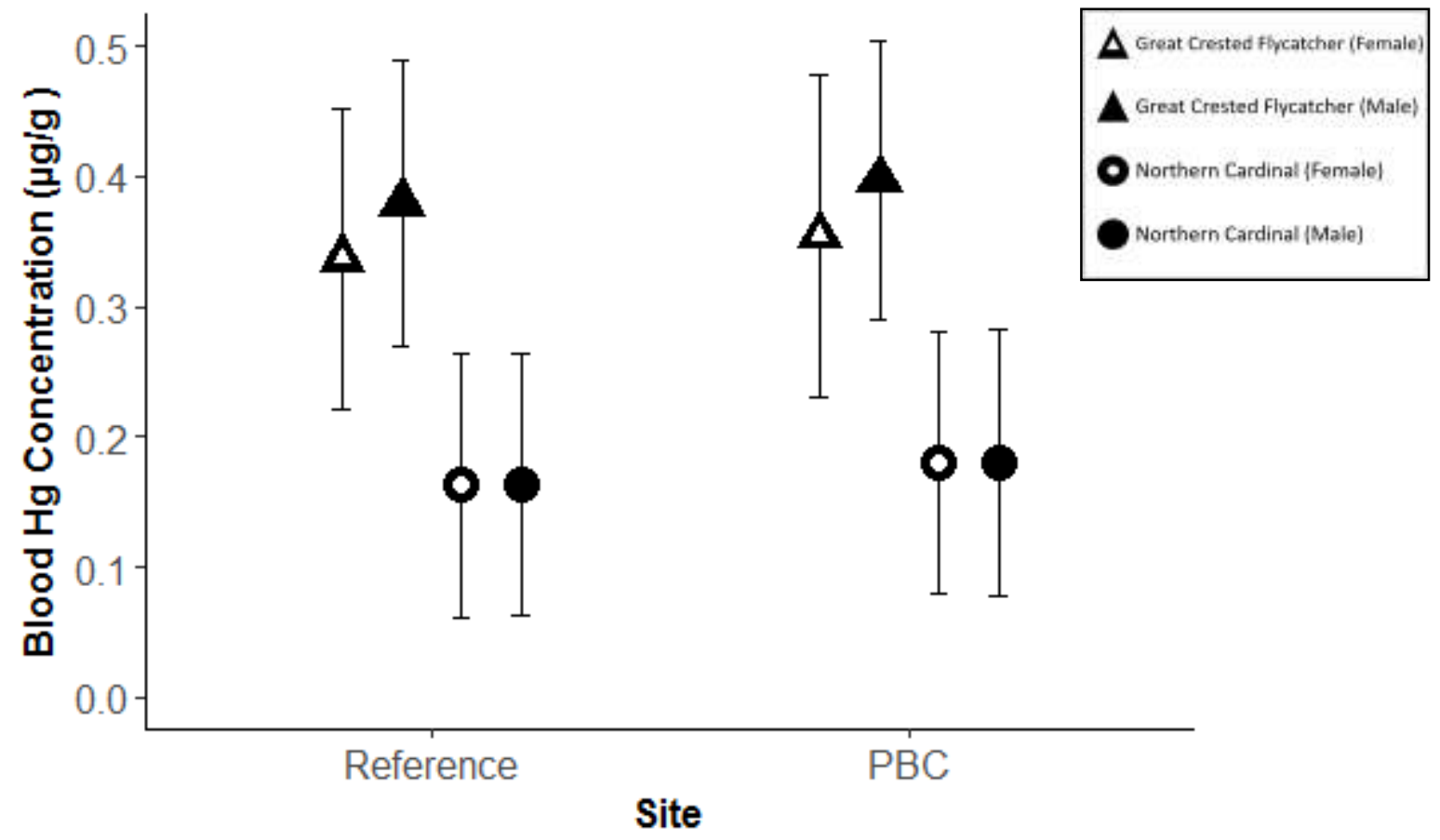

Figure 5: Predicted blood concentrations levels (wet weight) of mercury (Hg) after model averaging (85\% confidence interval) for Northern Cardinals (circles, $n=33$ ) by sex and Great Crested Flycatchers (triangles, $n=17$ ) by sex that were collected at the Savannah River Site April-June 2016.

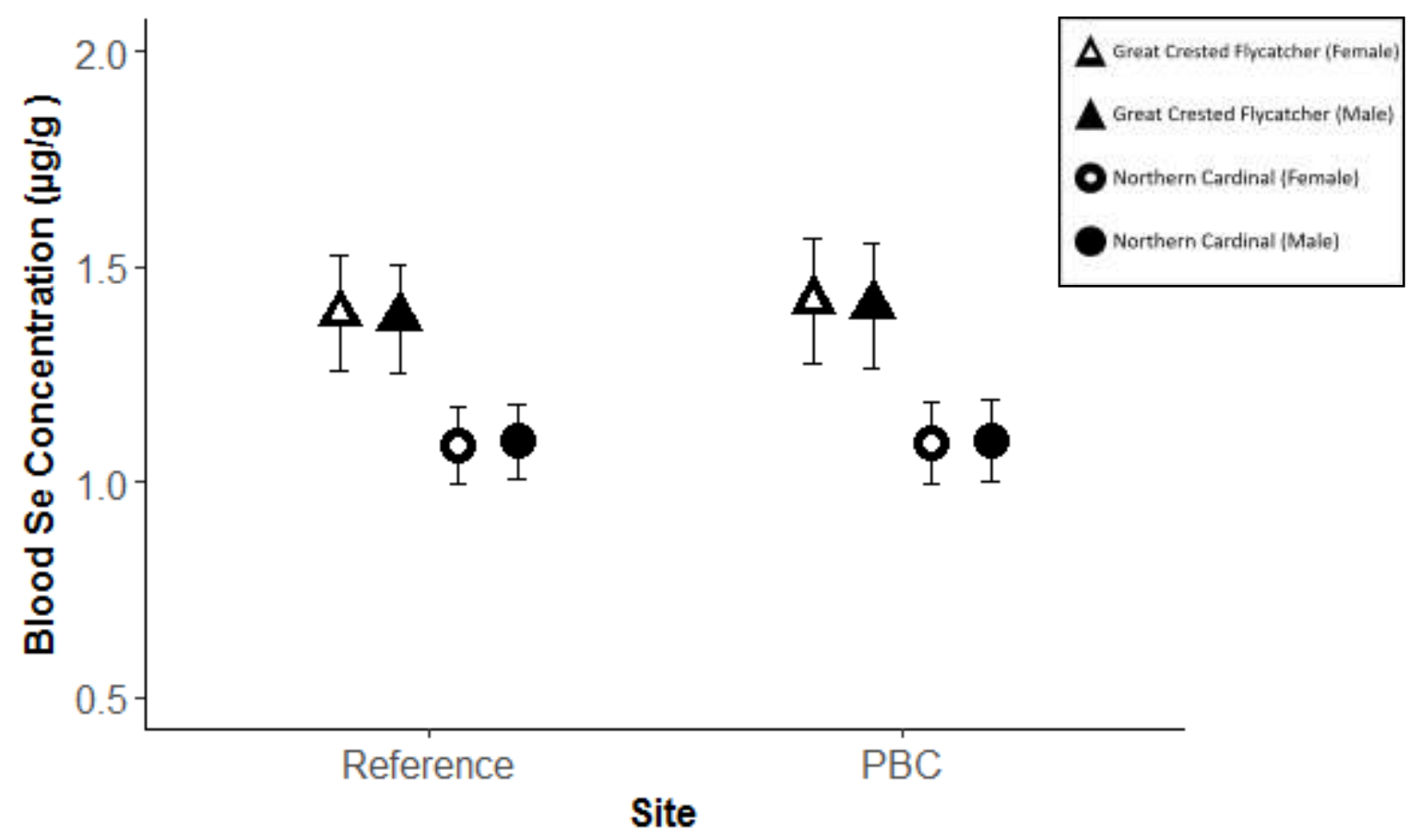

Figure 6: Predicted blood concentrations levels (wet weight) of selenium (Se) after model averaging (85\% confidence interval) for Northern Cardinals (circles, $n=41$ ) by sex and Great Crested Flycatchers (triangles, $n=19$ ) by sex that were collected at the Savannah River Site April-June 2016. 


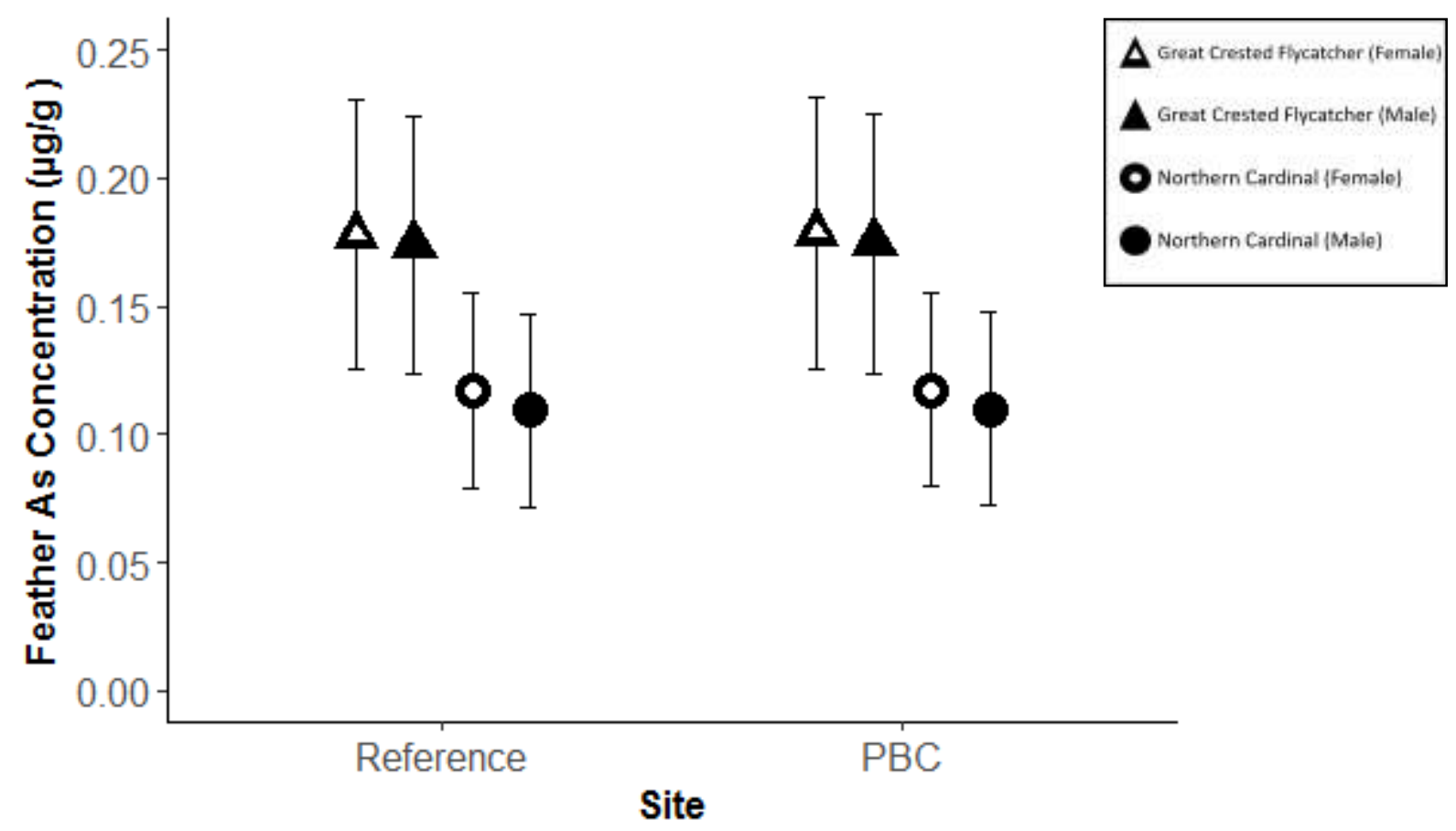

Figure 7: Predicted feather concentrations levels (dry weight) of arsenic (As) after model averaging (85\% confidence interval) for Northern Cardinals (circle, $n=50$ ) by sex and Great Crested Flycatchers (triangle, $n=20$ ) by sex that were collected at the Savannah River Site April-June 2016.

Zinc concentrations in feathers from reference locations, for both species combined, had an estimated 67 less $\mu \mathrm{g} / \mathrm{g}$ than in PBC sites $(\beta=-67.924,85 \% \mathrm{CL}=-128.705,-7.144$; Figure 4$)$ which is consistent with the close proximity hypothesis but not the migratory exposure hypothesis. Similarly, cardinals had lower concentrations of $\mathrm{Hg}(\beta=-0.174,85 \% \mathrm{CL}=-0.261$, 0.086; Figure 5) and Se $(\beta=-0.329,85 \% \mathrm{CL}=-0.500,-0.158$; Figure 6$)$ in blood samples than flycatchers. Arsenic levels were negligibly lower in cardinal feathers $(\beta=-0.061,85 \% \mathrm{CL}=-$ 0.116, -0.006; Figure 7) than in flycatchers. Sex differences between and among species were not significant for any metal analyzed based on $85 \%$ confidence intervals after model averaging.

3.1.2 Metal correlations between tissues

Cardinals exhibited a significant negative feather/blood correlation for $\mathrm{Cu}(r=-0.33, p=$ $0.038)$ but significant positive correlations for $\mathrm{Hg}(r=0.614, p<0.001)$ and $\mathrm{Pb}(r=0.408, p=$ 
0.008) (Table 3). Correlations between the two tissues types were not observed in flycatchers for any metal.

\subsubsection{Correlations between metals}

Cardinals had significant negative feather $\mathrm{Hg} / \mathrm{Se}(r=-0.329, p=0.026)$ and positive blood $\mathrm{Hg} / \mathrm{Se}$ correlations ( $r=0.464, p=0.007$ ) but $\mathrm{Hg} / \mathrm{Se}$ were not correlated in either tissue type for flycatchers (see Supplemental Material for figures). Feather concentrations of $\mathrm{Pb} / \mathrm{Zn}$ were also positively correlated for cardinals $(r=0.34, p=0.015)$ and marginally correlated for flycatchers $(r=0.43, p=0.059)$; however, $\mathrm{Pb} / \mathrm{Zn}$ blood concentrations were not correlated for either species.

\subsection{Discussion}

Overall, the lack of evidence supporting the close proximity hypothesis suggests that the bioavailability of historical heavy metal contamination to passerines on the SRS is minimal. While there may be areas of higher metal concentrations on the SRS, the spatial extent of the passerine exposure does not likely pose a risk to local population levels. This is due to the notion that only very few individuals are inhabiting areas immediately adjacent to contaminated areas which are susceptible to extremely high bioavailable concentrations. $\mathrm{Pb}$ and $\mathrm{Cd}$ are two metals of top concern in ecotoxicology however, Cd values were almost all below detection limit and no individual had higher than $0.5 \mu \mathrm{g} / \mathrm{g}$ in feathers or $0.15 \mu \mathrm{g} / \mathrm{g}$ blood for $\mathrm{Pb}$. Mercury (specifically methylmercury) is arguably, one of the most toxic compounds to humans and wildlife. The levels seen in this study however, fall below the threshold for negative reproductive consequences seen in a similar species (Jackson et al., 2011) and are therefore not concerning from a population level standpoint. Interestingly, feather concentrations of $\mathrm{Cr}, \mathrm{Cu}, \mathrm{Zn}$, and $\mathrm{As}$ found in this study contradict the migratory exposure hypothesis. This suggests that individual flycatchers are 
apparently being exposed to differing heavy metal levels during feather growth as they travel between their breeding grounds in the US and their wintering grounds in Central and South America. Copper and chromium levels were substantially higher (as compared to cardinals) in some individuals implying some flycatchers are wintering on areas with some residual bioavailable environmental pollution. Without geolocators on said individuals however, it is impossible to determine the geographic location of their wintering grounds.

\subsubsection{Sex-specific concentrations}

Sex-specific differences were not observed for metal concentrations which was relatively surprising given that females have been known to deposit heavy metals through eggs during the breeding season (Rimmer et al., 2005), although we were unable to confirm that the females we caught were actively nesting. Even so, the deposition of heavy metals in eggs has been disputed by Burger (2007) who found that female birds in general exhibited higher levels of heavy metals. Differing foraging habits between sexes of conspecific passerines have been identified (Holmes, 1986), but in these species it is likely that both sexes are maintaining approximately the same trophic level even with dissimilar diets. Sex differences in relation to mass are also not constantly observed for cardinals (Halkin and Linville, 1999) or flycatchers (Miller and Lanyon, 2014), but males have longer wing and tail lengths in both species. Bioaccumulation rates of heavy metals in both sexes of passerines specifically may be consistent (i.e. same uptake rate) due to similarities in diet between the sexes. Even though diet is the primary source of metal accumulation, however, the bioaccumulation rate is very species-specific (Burger and Gochfeld, 2000; Squadrone et al., 2016). While contrary to previous research in passerines (Jackson et al., 2011), subtle species specific food chain differences may affect bioaccumulation and should be explored in future research. 


\subsubsection{Species-specific concentrations}

Heavy metal deposition in feathers occurs during feather formation (Goede and de Bruin, 1984) and body feathers of flycatchers specifically form on or near wintering grounds before spring migration in Central or South America (Miller and Lanyon, 2014), whereas cardinals molt all their feathers in the fall, post-breeding season (Halkin and Linville, 1999). Due to the differences in geographic location during molting of body feathers, flycatchers were expected to have different heavy metal concentrations than cardinals regardless of treatment group effects (migratory exposure hypothesis), but this was only confirmed for certain metals: $\mathrm{Cr}, \mathrm{Cu}$, and $\mathrm{Zn}$.

Species differences in blood concentration levels at both reference and PBC locations (especially for $\mathrm{Se}$ and $\mathrm{Hg}$ ) suggest differences in trophic feeding levels between the two species (Abbasi et al., 2015; Deng et al., 2007). This is expected as flycatchers diet consists of $>90 \%$ invertebrates (Miller and Lanyon, 2014) while cardinal diet varies greatly throughout the year and are considered omnivores (De Graaf et al., 1985). Mercury (Keller et al., 2014; Newman et al., 2011; Scheuhammer et al., 2007) and possibly Se (Orr et al., 2006) biomagnify at increasing trophic levels which may indicate that flycatchers eat organisms at a higher trophic level than cardinals. Tissue correlation tests revealed that only $\mathrm{Cu}, \mathrm{Pb}$, and $\mathrm{Hg}$ in cardinals (not flycatchers) had any significant correlation which was expected because they are using resources from the same location year round. This trend between feather and blood concentrations was also seen in Burger (1993) with only Hg however and was not tested in passerine species (mostly seabirds and raptors) nor was there a difference noted between migratory and resident species. This distinction is vital to address when conducting blood/feather tissue correlations as one implicates recent exposure and the other, long term, which can help distinguish when and where contaminants were accumulated. Another consideration is that if migratory birds are wintering 
on contaminated sites and are killed or scavenged on their breeding grounds, this could lead to trophic transfer of harmful metals to resident predators.

Certain combinations of metals can have a synergistic effect which we may have slightly observed in this study. Mercury is a primary element of concern in avian ecotoxicology; however, a selenium- enriched diet has been shown to prevent mercury toxicity (Ralston and Raymond, 2010) by creating a stable complex. Cardinals had significant $\mathrm{Se} / \mathrm{Hg}$ correlations in both tissue types indicating protection from possible mercury toxicity (Parizek, 1978) and both metals are co-occurring at a predictable rate. Also, Dauwe et al. (2002) examined the influence of lead exposure on accumulation of $\mathrm{Zn}$ in feathers of zebra finches and found that it was lower when $\mathrm{Pb}$ intake was increased as well as a negative $\mathrm{Pb} / \mathrm{Zn}$ correlation in feathers. This contradicts the findings in our study as cardinals had a positive $\mathrm{Pb} / \mathrm{Zn}$ correlation (even though the correlation was weak). It should be noted however, $\mathrm{Pb}$ concentrations were extremely low potentially reducing the effect on higher amounts of $\mathrm{Zn}$.

\subsubsection{Site concentrations}

Legacy contamination effects on terrestrial wildlife (particularly songbirds) on the SRS after initial environmental introduction and cleanup is relatively unknown. In this study, two passerine species were sampled at reference locations and locations near areas of historical contamination. Based on blood levels, a direct indication of recent dietary exposure on their breeding territories, our results suggest no differences in local contamination for either species. Feather differences between sites did not exist for our resident species (cardinals) leading to the conclusion that PBC sites do not have bioavailable contamination. Feather differences between locations in flycatchers was explained in the previous section. In our study, sampling did not occur immediately adjacent to point sources which may have influenced metals uptake. 
Literature exists pertaining to contamination levels at different distances for smelters, resulting from air deposition (Dauwe et al., 2002; Eeva et al., 2008, 2006; Rogival et al., 2006), but no information was found pertaining to terrestrial bioaccumulation through water resources except those directly adjacent to the source (Bryan et al., 2012, 2003; Jackson et al., 2011). The residual contaminants may also be sufficiently contained such that bioavailability is low and bioaccumulation risk to terrestrial organisms is of minimal concern.

\subsubsection{Assessment of sampling techniques}

Non-lethal sampling of organisms is ideal, especially when dealing with sensitive or protected species such as migratory birds (Furness et al., 1986; Goede and de Bruin, 1984). Blood and feather samples taken from cardinals and flycatchers during their breeding season in this study provide information on heavy metal concentrations from a year-round perspective for both species. Blood levels, while not suitable for all metals, can be particularly informative about recent exposure to bioavailable concentration levels (Evers et al., 2005; Veerle et al., 2004) from their diet specifically (Furness and Greenwood, 1993). Feathers yield information at time of molt which, for these species, occurs outside the breeding season and for flycatchers occur across international boundaries. Feather metal concentrations vary with the specific metal (Lodenius and Solonen, 2013) and may include some atmospheric deposition, but that possibility was mitigated in this study through feather washing (Brait and Antoniosi- Filho, 2011). Breast feathers proved to be simple to collect and allowed for the entire feather to be analyzed, providing a more homogenous sample. However, contrary to other studies (Furness et al., 1986), breast feather concentration levels were not consistent when analyzed for $\mathrm{Hg}$ in our study. Sample duplicates (breast feathers from the same individual) had a 19\% (mean, $\pm 16 \%$ SD) difference in concentration levels between duplicate samples. This suggests that these feathers 
were grown at different time periods as older feathers have lower concentrations than new feathers (Ackerman et al., 2011; Spalding et al., 2000). Even though these feathers are from the same ventral feather tract, they are not all molting simultaneously. Further exploration of molting patterns and sequence for breast feathers in both species could supply an accurate indication of why these feathers are not all grown during the same timeframe.

\subsection{Conclusions}

Increasing available information on heavy metal concentrations of resident and migratory passerines is necessary to determine environmental pollution changes over time and potentially predict population level effects at a local and even global scale. Passerines can provide valuable information about the bioavailability of pollutants and serve as biological sentinels for remediation. Concentration levels observed in cardinals and flycatchers at the SRS during the 2016 breeding season suggested they were not accumulating SRS-based metals and that the existing concentrations were below known levels that would indicate toxicity concern. However, if migratory birds are wintering on contaminated sites and are killed or scavenged on their breeding grounds, this could lead to trophic transfer of harmful metals to resident predators. While information on the long-term impacts of metal loads at these concentrations is relatively unknown, especially for wild populations of passerines, there could be subtle consequences rendering negative influences on the fitness of specific individuals and potentially their offspring. Further research on breeding success and nestling fitness of passerines with similar heavy metal accumulation should be explored.

\subsection{Acknowledgements}

Thanks to three anonymous reviewers for their comments to improve our manuscript. Angela Lindell of SREL for help with DMA-80 analysis and prep work. Tori Andreasen for field 
collection and data input. This research was supported by DOE Award Number DE-FC09-

07SR22506 to the University of Georgia Research Foundation.

\subsection{References}

Abbasi, N.A., Jaspers, V.L.B., Chaudhry, M.J.I., Ali, S., Malik, R.N., 2015. Influence of taxa, trophic level, and location on bioaccumulation of toxic metals in bird's feathers: a preliminary biomonitoring study using multiple bird species from Pakistan. Chemosphere $120,527-37$.

Ackerman, J.T., Eagles-Smith, C. a., Herzog, M.P., 2011. Bird mercury concentrations change rapidly as chicks age: Toxicological risk is highest at hatching and fledging. Environ. Sci. Technol. 45, 5418-5425.

Arnold, T.W., 2010. Uninformative parameters and model selection using Akaike's Information Criterion. J. Wildl. Manage. 74, 1175-1178.

Bates, D., Maechler, M., Bolker, B., Walker, S., 2015. Fitting linear mixed-effects models using lme4. J. Stat. Softw. 67, 1-48.

Battaglia, A., Ghidini, S., Campanini, G., Spaggiari, R., 2005. Heavy metal contamination in little owl (Athene noctua) and common buzzard (Buteo buteo) from northern Italy. Ecotoxicol. Environ. Saf. 60, 61-66.

Bearhop, S., Waldron, S., Thompson, D., Furness, R., 2000. Bioamplification of mercury in Great Skua Catharacta skua chicks: the influence of trophic status as determined by stable isotope signatures of blood and feathers. Mar. Pollut. Bull. 40, 181-185.

Beyer, W.N., Meador, J.P., 2011. Environmental contaminants in biota. CRC Press LLC, Baton Rouge.

Bond, A.L., Lavers, J.L., 2011. Trace element concentrations in feathers of Flesh-footed Shearwaters (Puffinus carneipes) from across their breeding range. Arch. Environ. Contam. Toxicol. 61, 318-326.

Brait, C.H.H., Antoniosi- Filho, N.R., 2011. Use of feathers of feral pigeons (Columba livia) as a technique for metal quantification and environmental monitoring. Environ. Monit. Assess. 
$179,457-467$.

Braune, B.M., Donaldson, G.M., Hobson, K.A., 2002. Contaminant residues in seabird eggs from the Canadian Arctic. II. Spatial trends and evidence from stable isotopes for intercolony differences. Environ. Pollut. 117, 133-145.

Bryan, A.L., 2011. Trace element concentrations of aquatic biota from selected SRS aquatic systems: Support of the SRS trophic transfer modeling effort. Final project report to SRNSACP, Savannah River Site. Aiken, SC.

Bryan, A.L., Hopkins, W.A., Baionno, J.A., Jackson, B.P., 2003. Maternal transfer of contaminants to eggs in Common Grackles (Quiscalus quiscala) nesting on coal fly ash basins. Arch. Environ. Contam. Toxicol. 45, 273-277.

Bryan, A.L., Hopkins, W.A., Parikh, J.H., Jackson, B.P., Unrine, J.M., 2012. Coal fly ash basins as an attractive nuisance to birds: parental provisioning exposes nestlings to harmful trace elements. Environ. Pollut. 161, 170-177.

Burger, J., 2007. A framework and methods for incorporating gender-related issues in wildlife risk assessment: Gender-related differences in metal levels and other contaminants as a case study. Environ. Res. 104, 153-162.

Burger, J., 1993. Metals in avian feathers: Bioindicators of environmental pollution. Rev. Environ. Toxicol. 5, 203-311.

Burger, J., Gochfeld, M., 2002. Effects of chemicals and pollution on seabirds, in: Biology of Marine Birds. CRC Press LLC, pp. 485-514.

Burger, J., Gochfeld, M., 2000. Metal levels in feathers of 12 species of seabirds from Midway Atoll in the northern Pacific Ocean. Sci. Total Environ. 257, 37-52.

Burger, J., Gochfeld, M., 1996. Ideological and human health risk assessment: a comparison, in: Di Giulio, R.T., Monosson, E. (Eds.), Interconnections between Human and Ecosystem Health. Springer Netherlands, pp. 127-148.

Burnham, K.P., Anderson, D.R., 2002. Model selection and multimodel inference: a practical information-theoretic approach, 2nd ed. Springer, New York, New York. 
Cai, F., Calisi, R.M., 2016. Seasons and neighborhoods of high lead toxicity in New York City: The feral pigeon as a bioindicator. Chemosphere 161, 274-279.

Dauwe, T., Bervoets, L., Blust, R., Eens, M., 2002. Tissue levels of lead in experimentally exposed zebra finches (Taeniopygia guttata) with particular attention on the use of feathers as biomonitors. Arch. Environ. Contam. Toxicol. 42, 88-92.

Dauwe, T., Bervoets, L., Blust, R., Pinxten, R., Eens, M., 2000. Can excrement and feathers of nestling songbirds be used as biomonitors for heavy metal pollution? Arch. Environ. Contam. Toxicol. 39, 541-546.

Dauwe, T., Bervoets, L., Pinxten, R., Blust, R., Eens, M., 2003. Variation of heavy metals within and among feathers of birds of prey: Effects of molt and external contamination. Environ. Pollut. 124, 429-436.

Dauwe, T., Lieven, B., Ellen, J., Rianne, P., Ronny, B., Marcel, E., 2002. Great and blue tit feathers as biomonitors for heavy metal pollution. Ecol. Indic. 1, 227-234.

De Graaf, R.M., Tilghman, N.G., Anderson, S.H., 1985. Foraging guilds of North American birds. Environ. Manage. 9, 493-536.

Deng, H., Zhang, Z., Chang, C., Wang, Y., 2007. Trace metal concentration in Great Tit (Parus major) and Greenfinch (Carduelis sinica) at the Western Mountains of Beijing, China. Environ. Pollut. 148, 620-626.

Dickey, D.R., van Rossem, A.J., 1938. The birds of El Salvador, Field Museum of Natural History Zoological Series. Chicago.

Edwards, P.G., Gaines, K.F., Bryan, A.L., Novak, J.M., Blas, S.A., 2014. Trophic dynamics of $\mathrm{U}, \mathrm{Ni}, \mathrm{Hg}$ and other contaminants of potential concern on the Department of Energy's Savannah River Site. Environ. Monit. Assess. 186, 481-500.

Eens, M., Pinxten, R., Verheyen, R.F., Blust, R., Bervoets, L., 1999. Great and blue tits as indicators of heavy metal contamination in terrestrial ecosystems. Ecotoxicol. Environ. Saf. 44, 81-85. doi:10.1006/eesa.1999.1828

Eeva, T., Ahola, M., Laaksonen, T., Lehikoinen, E., 2008. The effects of sex, age and breeding 
success on breeding dispersal of pied flycatchers along a pollution gradient. Oecologia 157, $231-238$.

Eeva, T., Hakkarainen, H., Laaksonen, T., Lehikoinen, E., 2006. Environmental pollution has sex-dependent effects on local survival. Biol. Lett. 2, 298-300.

Evers, D.C., Burgess, N.M., Champoux, L., Hoskins, B., Major, A., Goodale, W.M., Taylor, R.J., Poppenga, R., Daigle, T., 2005. Patterns and interpretation of mercury exposure in freshwater avian communities in northeastern North America. Ecotoxicology 14, 193-221.

Fletcher, D.E., Lindell, A.H., Stillings, G.K., Mills, G.L., Blas, S.A., Vaun McArthur, J., 2014. Spatial and taxonomic variation in trace element bioaccumulation in two herbivores from a coal combustion waste contaminated stream. Ecotoxicol. Environ. Saf. 101, 196-204.

Fossi, M.C., Massi, A., Lari, L., Leonzio, C., Focardi, S., Marsili, L., Renzoni, A., 1995. Interspecific differences in mixed function oxidase activity in birds: A tool to identify “species at risk." Sci. Total Environ. 171, 221-226.

Furness, R., Greenwood, J.J., 1993. Birds as monitors of pollutants, in: Birds as Monitors of Environmental Change. Chapman \& Hall, London, pp. 86-143.

Furness, R.W., Muirhead, S.J., Woodburn, M., 1986. Using bird feathers to measure mercury in the environment: relationships between mercury content and moult. Mar. Pollut. Bull. 17, $1-4$.

Goede, A.A., de Bruin, M., 1984. The use of bird feather parts as a monitor for metal pollution. Environ. Pollution. Ser. B, Chem. Phys. 8, 281-298.

Halkin, S., Linville, S., 1999. Northern Cardinal (Cardinalis cardinalis), The Birds of North America Online (P. G. Rodewald, Ed.). Ithaca. doi:Retrieved from the Birds of North America: https://birdsna.org/Species-Account/bna/species/norcar

Hernández, F., Oldenkamp, R.E., Webster, S., Beasley, J.C., Farina, L.L., Wisely, S.M., 2016. Raccoons (Procyon lotor) as sentinels of trace element contamination and physiological effects of exposure to coal fly ash. Arch. Environ. Contam. Toxicol. 72, 235-246.

Holmes, R.T., 1986. Foraging patterns of forest birds: male-female differences. Wilson Bull. 98, 
196-213.

Hopkins, W.A., Mendonça, M.T., Rowe, C.L., Congdon, J.D., 1998. Elevated trace element concentrations in southern toads, Bufo terrestris, exposed to coal combustion waste. Arch. Environ. Contam. Toxicol. 35, 325-329.

Jackson, A., Evers, D.C., Etterson, M.A., Condon, A.M., Folsom, S.B., Detweiler, J., Schmerfeld, J., Cristol, D.A., 2011. Mercury exposure affects the reproductive success of a free-living terrestrial songbird,the Carolina Wren (Thryothorus ludovicianus). Auk 128, 759-769.

Jetz, W., Freckleton, R.P., McKechnie, A.E., 2008. Environment, migratory tendency, phylogeny and basal metabolic rate in birds. PLoS One 3, e3261.

Keller, R.H., Xie, L., Buchwalter, D.B., Franzreb, K.E., Simons, T.R., 2014. Mercury bioaccumulation in Southern Appalachian birds, assessed through feather concentrations. Ecotoxicology 23, 304-316.

Kilgo, J.C., Blake, J.I., 2005. Ecology and management of a forested landscape: fifty years on the Savannah River Site. Island Press, Washington.

Lodenius, M., Solonen, T., 2013. The use of feathers of birds of prey as indicators of metal pollution. Ecotoxicology 22, 1319-1334.

Loehle, C., Paller, M., 1990. Heavy metals in fish from streams near F-area and H-area seepage basins: WSCR-RP-90-482. Westinghouse Savannah River Company, Aiken, SC.

Miller, K.E., Lanyon, W.E., 2014. Great Crested Flycatcher (Myiarchus crinitus), The Birds of North America Online (A. Poole, Ed.). Ithaca. doi:Retrieved from the Birds of North America: https://birdsna.org/Species-Account/bna/species/grcfly

Movalli, P.A., 2000. Heavy metal and other residues in feathers of laggar falcon Falco biarmicus jugger from six districts of Pakistan. Environ. Pollut. 109, 267-275.

Nakagawa, S., Schielzeth, H., 2013. A general and simple method for obtaining R2 from generalized linear mixed-effects models. Methods Ecol. Evol. 4, 133-142.

Newman, M.C., Xu, X., Condon, A., Liang, L., 2011. Floodplain methylmercury 
biomagnification factor higher than that of the contiguous river (South River, Virginia USA). Environ. Pollut. 159, 2840-2844.

Orr, P.L., Guiguer, K.R., Russel, C.K., 2006. Food chain transfer of selenium in lentic and lotic habitats of a western Canadian watershed. Ecotoxicol. Environ. Saf. 63, 175-188.

Parizek, J., 1978. Interactions between selenium compounds and those of mercury or cadmium. Environ. Health Perspect. 25, 53-55.

R Core Team, 2015. R: A language and environment for statistical computing, in: R Foundation for Statistical Computing. Vienna, Austria. doi:https://www.r-project.org

Rainio, M.J., Kanerva, M., Wahlberg, N., Nikinmaa, M., Eeva, T., 2012. Variation of basal EROD activities in ten passerine bird species - relationships with diet and migration status. PLoS One 7, e33926.

Ralston, N.V.C., Raymond, L.J., 2010. Dietary selenium's protective effects against methylmercury toxicity. Toxicology 278, 112-123.

Rimmer, C.C., Mcfarland, K.P., Evers, D.C., Miller, E.K., Aubry, Y., Busby, D., Taylor, R.J., 2005. Mercury concentrations in Bicknell's thrush and other insectivorous passerines in montane forests of northeastern North America. Ecotoxicology 14, 223-240.

Robinson, S. a, Lajeunesse, M.J., Forbes, M.R., 2012. Sex differences in mercury contamination of birds: Testing multiple hypotheses with meta-analysis. Environ. Sci. Technol. 70947101.

Rogival, D., Scheirs, J., De Coen, W., Verhagen, R., Blust, R., 2006. Metal blood levels and hematological characteristics in wood mice (Apodemus sylvaticus $L$. ) along a metal pollution gradient. Environ. Toxicol. Chem. 25, 149-157.

Rowe, C.L., Kinney, O.M., Fiori, A.P., Congdon, J.D., 1996. Oral deformities in tadpoles (Rana catesbeiana) associated with coal ash deposition: effects on grazing ability and growth. Freshw. Biol. 36, 723-730.

Scheifler, R., Coeurdassier, M., Morilhat, C., Bernard, N., Faivre, B., Flicoteaux, P., Giraudoux, P., Noël, M., Piotte, P., Rieffel, D., de Vaufleury, A., Badot, P.-M., 2006. Lead 
concentrations in feathers and blood of common blackbirds (Turdus merula) and in earthworms inhabiting unpolluted and moderately polluted urban areas. Sci. Total Environ. 371, 197-205.

Scheuhammer, A.M., 1987. The chronic toxicity of aluminium, cadmium, mercury, and lead in birds: A review. Environ. Pollut. 46, 263-295.

Scheuhammer, A.M., Meyer, M.W., Sandheinrich, M.B., Murray, M.W., 2007. Effects of environmental methylmercury on the health of wild birds , mammals , and fish. R. Swedish Acad. Sci. 36, 12-18.

Solonen, T., Lodenius, M., 1990. Feathers of birds of prey as indicators of mercury contamination in southern Finland. Holarct. Ecol. 13, 229-237.

Spalding, M.G., Frederick, P.C., McGill, H.C., Bouton, S.N., McDowell, L.R., 2000. Methylmercury accumulation in tissues and its effects on growth and appetite in captive great egrets. J. Wildl. Dis. 36, 411-422.

Squadrone, S., Abete, M.C., Brizio, P., Monaco, G., Colussi, S., Biolatti, C., Modesto, P., Acutis, P.L., Pessani, D., Favaro, L., 2016. Sex- and age-related variation in metal content of penguin feathers. Ecotoxicology 25, 431-438. doi:10.1007/s10646-015-1593-7

Veerle, J., Tom, D., Rianne, P., Lieven, B., Ronny, B., Marcel, E., 2004. The importance of exogenous contamination on heavy metal levels in bird feathers. A field experiment with free-living great tits, Parus major. J. Environ. Monit. 6, 356-360. 